\title{
Lads in Waiting: Another 'Crisis'. An Exploratory Study on the Indian 'Fresher' Rating Seafarers
}

\author{
Peidong Yang, Cardiff University
}

\begin{abstract}
Studies on work/labour precarity in recent decades have pointed out its close connections with neoliberal globalisation. While maritime shipping, arguably the most globalised of all contemporary industries, has always been recognised as a singularly precarious sector where seafarers exhibit vulnerabilities towards various forms of exploitation, what has not been sufficiently recognised is an emergent and increasingly manifest polarisation within the industry. Whilst much emphasis has been laid on a so-called 'manning crisis', namely, an acute industry-wide shortage of qualified seagoing officers, little is known about an equally undesirable oversupply of ratings, especially at the junior/trainee level. This oversupply results in an employer's market, rendering seafaring particularly precarious for the ratings, which maybe seen as another crisis. This paper seeks to explore the oversupply of ratings from a localised, 'ground-level' perspective by looking at the lived experiences of a group of job-seeking 'fresher seamen' based at a 'Seamen's Hostel' in a major maritime city of India. Using a mixture of quantitative and qualitative methods, the paper explores the situation of these 'lads in waiting', the various difficulties they face, and their vulnerabilities. Finally, it makes some attempts at understanding the causes of the problem from a policy angle, and suggests that a better information system, and a more integrated regulatory approach, among other things, are areas in which Indian policy makers can put in effort to tackle the problem.
\end{abstract}

\section{KEY WORDS}

India, precarity, oversupply, rating, seafarer

\section{Introduction}

One prominent theme in labour studies of recent decades has been that of precarity or, less often, casualisation (Kalleberg 2009, Theodore 2002). The concept of precarity is a matter of definition, and can be ambiguous (Rodgers and Rodgers 1989). Since in this article, the concept itself and its intricacies are not the direct concern but 
merely serve to provide a theoretical index, the term is employed generically to mean the instability and casualness of work, and consequently workers'various forms of vulnerability. Explanations of the ascendancy of precarious work are also multifarious, but have usually pointed to factors such as mass labour mobility/migration, global production outsourcing, technological advances, and more significantly, worldwide neoliberal ideological shifts and the structural changes that subsequently occurred to economic/regulatory systems and labour market relations. In other words, neoliberal globalisation is commonly seen as lying fundamentally behind the increasing pervasiveness of work precarity. Given this, it is surprising that within the massive body of literature on precarious work/labour and the conditions of workers under such terms, attention has rarely been paid to seafarers working in maritime shipping, argued to be the most globalised of all contemporary industries (Glen 2008, Sampson 2003, 2004), which, as this paper will show, is also characterised by a high degree of precariousness and casualisation and all the associated negative implications. To this extent, looking into the precariousness of global maritime labour is not only a useful addition to the general scholarship on labour conditions in the globalised late-industrial society, but by focusing on this singularly globalised sector, it also presents an opportunity to glimpse how precarity and labour vulnerability can be manufactured transnationally and globally.

Although a globalised seafaring labour market had practically existed for centuries, not least in connection with Western colonial trades (Frost 1995, Slater 1984), this was effectively institutionalised through the system of Flag of Convenience (FOC) since the mid twentieth century (Metaxas 1985, Lillie 2006), which allowed shipowners predominantly from the developed world to 'pick and choose' lax regulatory regimes worldwide (notable examples include Panama and Liberia, see Carlisle 1981) in which to register their companies and vessels, a practice known as 'regime shopping'. Among various cost cutting and regulation avoiding opportunities presented by the FOC system to the shipowners, the most significant one is the possibility of recruiting seafaring labour from developing countries at significantly lower costs (Alderton and Winchester 2002, Thanopoulou 1998), since human cost easily accounts for half of shipowners' ship operating costs (Stopford 1997). Populous developing counties such as the Philippines and India, on the other hand, have responded positively by adopting the systematic training and supply of seafarers as their national economic strategies, motivated by the employment opportunities and the associated huge foreign currency income potential. Given these general configurations and the inherently tough nature of working at sea, the seafaring profession has always been one singularly characterised by precarity, with seafarers exposed to abuses of all kinds across the industry (Alderton et al. 2004, Chapman 1991, Couper, Walsh, Stanberry and Boerne 1999, Slater 1984). However, under such general observation, what has not been sufficiently recognised is an emergent and increasingly manifest polarisation of the experience of the practitioners of seafaring, along the lines of their skill and work experience.

For those familiar with the global shipping industry, it is by now a cliché to say that there is a 'manning crisis'. In BIMCO/ISF Manpower Update (2005), the worldwide demand for maritime officers (i.e. relatively highly skilled and experienced personnel holding significant positions onboard vessels) was estimated to be 488,000 , while the 
global supply 467,000 in 2010 , indicating a shortage of 21,000 (about $5 \%$ ), and that shortfall was predicted to grow to 27,000 by 2015 (5.9\%). However, more recent reports from the industry suggested that the officer shortfall could rise to 56,000 by just $2013^{1}$ indicating a rapidly deepening 'crisis'. Although some scholars (Leggate 2004, Li and Wonham 1999) have expressed doubts regarding the nature and real extent of the shortage, the 'crisis' as a potent discourse has undoubtedly had its concrete impacts, evidenced by the numerous conferences and seminars held in recent years by both public and private maritime industry stakeholders worldwide, aimed at tackling this 'crisis' (e.g. Donner 2009). According to International Ship Managers' Association ${ }^{2}$ the demand for seafarers has not declined even in the current global economic downturn.

However, it is not difficult to realise that this industry-wide discourse of the 'manning crisis' is conceived of from the sole perspective of employers, for it presupposes that what is in short supply is a crisis, whereas the chronicled oversupply of ratings (i.e. seafarers with lower skills/experience occupying lesser positions on ships) and the pernicious consequences are seldom mentioned. In the same 2005 BIMCO/ISF report, the worldwide supply of ratings in 2010 was estimated to be 740,000 with the demand only 598,000, resulting in a surplus of 142,000 ratings, and this surplus was expected to grow to 167,000 in 2015 . More updated figures/estimates seem less readily available, presumably due to a lack of interest. For the industry, because there is an abundant supply of ratings, there is nothing to worry about - there is no 'crisis'.

This paper proposes, however, that such a supply and demand situation places officers in an advantageous position, evidenced by improving wages and employment benefits across the board in the industry (Matthews 2007: 38, Shao, Yang, and Zhang 2008), whereas in contrast, the position of the ratings is increasingly pushed towards 'precarity'. Not only has there been evidence of a general downward pressure on wages (Zhao and Amante 2003), the sustained oversupply also means that ratings are more liable to casual hire and fire, and various forms of injustice. In other words, they are the ones that are truly facing a 'crisis', especially those inexperienced ratings looking for work for the first time, known as 'freshers'. Though outside the maritime field, up-to-date examples can be found of ethnographic studies on casual day-job seekers in 'hiring halls' or street corners (e.g. Cleaveland and Pierson 2009, Purser 2009, Williams 2009), within the maritime field, research concerning seafarers has seldom made the conscious distinction between officers and ratings ${ }^{3}$ and even those rare ones which do tended to focus on training (e.g. Bonnin, Lane, Ruggunan and Wood 2004), with little attention paid to the daily experience of job-seeking ratings. Obando-Rojas mentioned a few years back (2003) that in the labour supply countries, there was a rise in the unemployment of 'general purpose' ratings, but did not study the issue more closely. Chapman's book Trouble on Board (1991) touches on some aspects of the difficult experience of job-seeking ratings, however, this account is now dated, and Chapman relies mostly on anecdotes obtained in his capacity as a port chaplain instead of field-based research. Otherwise, the oversupply of ratings and its impacts on the lived experience of ordinary seamen seem an issue not very well understood, and tends to be a bit of an 'elephant in the room' in maritime research or policy discourse.

This study thus furnishes a much needed piece of knowledge by looking at a 
group of Indian 'fresher seamen' who have completed their rating training, obtained their certificates, and who are currently staying in a 'Seamen's Hostel' in a traditional maritime city of India in search of jobs. While examining predominantly from a localised perspective, insofar as I try to shed light on a globally prevalent phenomenon by ethnographically examining its manifestations in a specific locale nevertheless imbricated in a nexus of globally operating forces, this study can be in a sense seen as a mini application of Michael Burawoy et al's (2000) concept of 'Global Ethnography' in relation to the precarity experienced by job-seeking ratings.

The structure of the paper is as follows. First of all, some background information on seafaring in the Indian context is given, in order to set the backdrop of the story. Fieldwork and methodological issues are mentioned subsequently, before the main body of the paper presents a rounded exploration of the fresher seamen's situation, using both quantitative and qualitative descriptions. Finally, some discussion and recommendations are made.

\section{Background: The Neoliberalisation of Indian Seafarer Supply}

Owing to its key position on the trade routes of the British Empire, India has been an important maritime nation over the last few centuries, not least because of its significant contribution to the global maritime labour pool (Desai 1940). After national Independence in 1947, against the backdrop of decolonisation, nationalism and post-War socialism, seafarer training in India was systematised and taken under direct state control (Rao 1965). According to the website of the Directorate General of Shipping ${ }^{4}$ of India, not only were the pre-sea training institutes directly run by the government in order to monitor supply to match estimated demands, the employment processes of seafarers across the country were also managed by state bureaus on rotational bases, in order 'to ensure fair distribution of employment among available seamen and eradicate malpractices in recruitment which had prevailed for a long time' (Rao 1965: 157).

Due to the cyclical nature of the shipping business, however, by the late 1970 s and the beginning of 1980s, there was a huge surplus of ratings, leading to alarming levels of unemployment. According to one source (Barnes 1989: 123, Table XXIV), at the beginning of 1980 in Bombay, 26,900 ratings were registered but the number of jobs available was only 16,668, leaving 38\% of the ratings unemployed. By 1987 that figure had risen to an astonishing $56.25 \%$.

The government shut down all three institutes in 1983 in response, which proved to be an unwise decision, for by the end of 1980s the demand had revived. Perhaps due to the flaws of the state-controlled system exposed through such experiences, in 1991 the Indian Government decided to devolve the responsibility of seafarer training to the industry, to be regulated by market mechanism. Putting this in a wider context, it is worth noting that 1991 was the same year in which India took onboard the IMF Structural Adjustment Programme, and the country was undergoing profound market-oriented economic reforms.

In 1995, bold privatisation of seafarer training and the discontinuation of the state-managed rotation system were further adopted. From 1998 onwards, private 
training institutes were allowed to be established on market principles subject to government approval, but without the need of demand-supply monitoring. The impacts of these policy changes were most manifest in the training of ratings, since its vocational nature meant enormous potential for commercialisation. Foreign shipping companies took advantage of the lower labour cost in India by either setting up their own recruiting branches or utilising local recruiting agencies. Consequently, rating training institutes mushroomed, and it is generally agreed among industry stakeholders that standards have been compromised as a result.

At the time of writing, there are a total of 125 government approved private training institutes in India, conducting training programmes for both officers and ratings. During the year 2009, the approved total capacity of all officer training courses was 6975 , whereas the actual intake fell short at 4752. Reflecting the industry-wide shortage of officers, shipping companies usually engage trainee officers either before their training starts or prior to their graduation, to a large extent providing de facto guaranteed employment. In contrast, any rating aspirant, as long as he satisfies the minimum entry requirements (usually '10-pass', equivalent to completion of secondary education), can apply to train and obtain a certificate in just six months. At present, across India there are 48 institutes providing rating training, with a total capacity of 5716. The actual intake during 2009 was 4966, which should also be roughly the number of ratings released into the job market in the same year. Although this figure is only slightly above that for officers, in view of the already over-flooded ratings market, it is a considerably high number.

The coincidence of the privatisation of the training of ratings and the deregulation of their employment plunged this large workforce into the high sea of supply and demand. Unlike their lucky officer counterparts, there is no company sponsorship, nor any guarantee of jobs. After obtaining their certificates, many of these 'freshers' come to a traditional port city - which is also probably the largest metropolis on the west coast of India to try their luck.

\section{FIELDWORK AND METHODS}

This study is based on the work I undertook as part of my research degree at Cardiff University, for which I spent two months in the above mentioned Indian maritime metropolis during the winter of 2009/10. Many trainee ratings searching for jobs in the city are lodged in a purpose-built 'Seamen's Hostel', which accommodates up to 2,000 men, which constituted the primary site of my investigations. With the approval of its governing body, I was able to visit the Hostel on six separate trips to conduct this study. My visits usually lasted several hours long and took place during evenings and weekends when most residents would stay in. On these visits, I was able to use mainly three types of research method, but in a flexible and mixed manner.

The leading thread of my investigations in the field was the conducting of a questionnaire-based survey. To avoid undesirable complications, only fresher seamen who had strictly no sea experience were included. It should be obvious, however, that their experience holds essentially true for those now-experienced seamen who grew out of the same stage. Due to the unpredictable movements of residents in the Hostel, distributing 
questionnaires in a centralised way proved difficult. Instead, I adopted the simple method of knocking on every single door and inviting freshers to participate in the survey individually. Eventually, 147 valid questionnaires were completed and this, by my estimation, accounts for more than half of the 'freshers' residing in the Hostel, and should be seen as a representative sample of a far greater body of freshers in this city and across India. Data collected were later entered into SPSS for simple statistical analysis, and this provides the quantitative descriptions to be presented in this paper.

More importantly, with hindsight, the 'simple' method that I used turned out to be highly rewarding, for entering each and every room maximised my interaction with the informants and hence enabled me to obtain as good a grasp of their situation as was possible during the limited time available. In the course of the research, I entered literally over a hundred rooms and spoke to hundreds of seamen, and this provided me with materials that constitute the qualitative aspects of my data, in the form of ethnography and interviews.

Detailed ethnographic data are produced through observing, listening, and experiencing, albeit temporarily, the lives of the fresher ratings in the Hostel. While temporary experience admittedly fails the stricter definition of ethnography, which requires extended immersion (Hammersley and Atkinson 1995), Sampson (2005) has convincingly demonstrated that under restricted circumstances, even this type of 'mini ethnography' can be highly illuminating. The fact that I was an outsider (being a foreigner and first-time visitor to India) to the field also meant that I was highly sensitive to what I saw and did not take things for granted. In other words, I was able to take advantage of the position of being an anthropological 'outsider' (Hendry 2003, Venkatesh 2002).

Meeting many friendly and enthusiastic freshers also enabled me to conduct many informal interviews, though most such interviews were unrecorded because the responses were typically fragmented and brief. This meant that after-scene reconstruction had to be used from time to time. On the other hand, interviews with various other stakeholders in the Indian shipping sector, such as policy makers and trade unionists, which I undertook after the Hostel fieldwork, were mostly tape-recorded and transcribed. In what follows, only a very small portion of my data can be presented, though I have endeavoured to make them as representative as possible to paint a rounded picture.

\section{Lads in Waiting}

\section{PROFILE}

According to the Hostel management, in the past decade, each year in and out more than 10,000 seamen have utilised this facility. The seamen demographic can be divided into two broad categories: the freshers, which are the focus of this paper, and the experienced. The latter can be further divided into two sub-categories. Some experienced seamen stay in the Hostel also in order to carry out job hunting, though their job hunting is significantly easier compared to the freshers. The other sub-category consists of 
those 'lucky' seamen who are waiting to 'join ship' shortly and those 'happy' seamen who have just signed off from ships, staying temporarily in the city before going back to their hometowns for holidays. The 'lucky' and 'happy' stay for the shortest periods, typically no more than one or two weeks, whereas those looking for work necessarily stay for longer. However, waiting for the experienced seamen is nothing compared to that of the freshers. Naturally, these freshers also stay in the Hostel for the longest periods, which is why I call them the 'lads in waiting'.

The lads in waiting that I sampled in the survey are all young men aged between 19 and 30, and the vast majority (85\%) lie between 20 and 25. Nearly three quarters $(74.6 \%)$ of them have completed their training in the past four years, i.e. between 2006 and 2009. These freshers hailed from 16 different states of India, but there seems to be some concentration from rural states such as Kerala (22.3\%), Uttar Pradesh (15.4\%), Bihar (13.8\%) and Tamil Nadu (9.2\%). Their educational levels ranged from '10-pass' $(18.9 \%)$ to graduate degree $(13.3 \%)$, but the bulk $(67.8 \%)$ have '12-pass', roughly equivalent to completion of high school.

Most trainee seafarers come from ordinary family backgrounds, as $50 \%$ of all respondents rated their family financial situations as 'Poor', another $46 \%$ as 'Average', and only less than $4 \%$ as 'Above Average'. This is well matched by the respondents' replies to a question which asked about their lifestyles in the hostel, with only $2 \%$ choosing 'Extravagant: Spend a lot and enjoy life', 43\% saying 'Normal: don't spend too much, just normal life' and the rest, 55\% saying 'Thrifty/Frugal: want to save every rupee'.

Those who choose 'Average' or 'Normal' also tended to call themselves 'middle class', though this label seems to be used in the Indian parlance rather differently than the term might mean in a western context, for the average monthly expenses reported by my participants is just 4017 Indian rupees 5 or 85 US dollars, and the majority of respondents (70\%) reported to spend between 2500 and 5500 rupees per month.

Keeping expenses low is essential for every fresher, because they have no idea how long their waiting period is going to be. In fact, this is the very reason many freshers choose to stay in this Hostel. With usually 15 people sharing a room meant for six, and on average 40 people sharing one toilet and shower, the condition at the Hostel is extremely uncomfortable by Western standards. However, the Hostel charges only 20 rupees per night, and it is this low cost that enables the freshers to carry out sustained search for jobs in a city that is probably the most expensive in India. For example, the most extreme case I encountered was a person who claims to have stayed in the Hostel on and off for some seven and a half years and still has not found his first job! Extreme cases aside, the average reported waiting time is 17 months, and on average a fresher has spent nearly 10 of these 17 months living in the Hostel.

\section{WAITING}

During their waiting period at the Hostel, most freshers receive remittance from family to cover their living costs. Some of them engage in casual jobs to earn some extra income, the typical choice being catering service. An entire day's shift of 15 hours (!) brings in 350 rupees, and a half day shift 175 . But even if a fresher chooses to take this meagrely paid and demanding job, I was told that he usually cannot do it more than four 
or five times a month, because his priority still lies with looking for a seafaring job. The proportion of freshers doing catering service is not high, and the seamen seemed to shy away from admitting to doing it because of its service nature. This concurs with Purser's (2009) interesting finding that even people trapped in dire situations somehow struggle to maintain or re-construct dignity and masculinity.

In one of my visits to the Hostel, I had an opportunity to speak to a boy with 10-pass education who was just about to start his pre-sea training at one of the government-approved seafaring colleges. Although this means he had not officially joined the 'lads in waiting' category, a casual talk with him generates some insights into the psychology of those young men who have decided to pursue seafaring. Unsurprisingly, good salary is the main motivation, and he said he was mainly inspired by a friend from his locality, who is now an experienced seaman, earning a 'handsome salary'. I asked him if he knew it would be difficult to find a job after completing training, to which he replied yes. I pursued this by asking him why then he still chose the profession, but his broken English - or my total incompetence in Hindi - prevented the conversation from going further. A senior seaman in his 40s came to help, explaining what that boy might have to say. Indeed, whatever this inexperienced boy might have to say about seamanship is all fed from his seniors, because more than merely an accommodation facility, the Hostel is also a space for peer socialisation where seniors share with their juniors information, knowledge and practical wisdom about seafaring. The senior seaman said:

Being seamen is all depend on luck. Just one word I tell you: luck. Some people wait for two years three years cannot get job, but another seaman wait for two months three months he can get job. So, yes, it is difficult to find job...but in fact you can't say anything. It also depends on your relationship and reference. If you have good relationship and reference then you have job. So it's all luck. Seamen is all luck.' (reconstruction in fieldnotes, 2009; emphasis added)

This explanation of 'luck' is reflected in the freshers' response to my survey question 'Do you think you can find a ship to join soon?' Those who answered 'Yes' and 'Don't know' accounted for almost $80 \%$, whereas those who chose 'No' were only slightly above $15 \%$. This is despite all freshers telling me how difficult it is to find a job. The 'relationship' and 'reference' mentioned by the senior seaman here allude to the fact that the roles of nepotism, favouritism, and personal connections have become accentuated in securing employment in a flooded labour market. However, for the vast majority of freshers who have no such 'relationship' or 'reference', what are the implications? This shall be returned to shortly.

\section{HOSTEL LIFE}

The patterns of seamen's lives in the Hostel are actually simple. For the 'happy' and 'lucky' seamen, they can enjoy every minute of their stay by having alcohol with their mates or going out to enjoy the exciting metropolitan life provided by this cosmopolitan city. For the rest who are looking for work, especially the freshers, however, job-hunting occupies most of their time and energy. In evening and weekends, they mostly pursue 
cheap 'time pass' activities by playing cards, watching telly (two tellies are shared by the entire Hostel) or DVD (on portable DVD-players owned by 'richer' seamen who have earned salary), going to the market to shop for food, or simply taking a day-time snooze in the Hostel.

For young men of their age to stay in such a compact hostel with near 2,000 other men while facing severe difficulties in seeking jobs, the freshers are experiencing considerable frustrations, which can be expected to encourage drug and alcohol use. In this regard, my survey shows that only $10 \%$ of freshers smoke, and just about $8 \%$ of them drink alcohol, which seem surprisingly low. My personal observations, however, led me to suspect that there is considerable deflation in such figures. On not a few questionnaires, the answers to the question 'Do you drink alcohol?' were altered from 'Yes' to 'No'. In several cases when the participants were filling in the questionnaires in my presence, a sense of shyness could even be detected from their faces. The actual figures of people taking drugs and alcohol are likely to be higher, though the extent is beyond ascertaining. The explanation turned out to be: although I had always made it a point to explain that I was a researcher from a university and that I was doing this survey purely for research purposes, rumours still spread that I was an undercover seamen recruiting agent and that the survey questionnaire was really a job application form! Believing that the information given would have implications for their employment prospects, the freshers perceived it was in their interest to present the image of candidates of good character and habit. Also, throughout my survey, the single question that had been unfailingly thrown at me was: 'will I get a job after filling this form?' - something I wished I had been able to do. The freshers' eagerness in cooperating with my survey and their timidity in even admitting such common habits as smoking and drinking to an irrelevant stranger passing through their lives tell in another way just how vulnerable these freshers are.

\section{STRATEGIES FOR JOB-HUNTING}

When it comes to searching for jobs, the freshers' strategies roughly fall into three categories. First of all, most freshers will try visiting the companies directly. These companies may be the India agent companies of large global shipping companies; they can be global crewing companies; or they can be smaller coastal shipping businesses. Regarding the response that the freshers receive from these companies, my many informants unfailingly gave the same description: the company would take their resumés, and tell them that there is no vacancy for fresher/trainee, and they might as well go. Sometimes, the companies do not even accept resumés, simply putting up a notice on the door saying that no fresher need enter. Even with those companies who are nice enough to take the resumés, the freshers have no faith in them, as one fresher vividly described to me 'they take your resumé, and when you go, the put it in the bin! Or maybe they have food on your resumé, after, throw way!' Clearly, in a labour market where there is an abundant supply of experienced seamen, inexperienced ratings are less desirable choices because of the on-job training that has to be invested in them. For those freshers unarmed with any 'relationship' or 'reference', their visits to potential employers are like cold calls, unlikely to receive any positive response. It consequently becomes necessary for 
the freshers to create their own 'relationship' and 'reference', or, if they are desperate, to buy them. This leads us to the two other common strategies.

The second way to look for jobs is through 'agents', who are middlemen well-connected to seafarer employers. These agents are by no means government registered crewing agencies; instead, they are typically the friends or relatives to people in the shipping companies; sometimes they may be actually working in crewing companies themselves, or are seasoned seafarers who through years of practicing the trade have accumulated an economically exploitable handful of personal connections. These agents usually loiter around the areas where shipping companies are concentrated or where the freshers stay, and they are sharp in recognising who the needy freshers are. They would approach the freshers, telling them that they are from so and so company, or they have such and such connections. They promise the freshers that they can get them some vacancies, of course, subject to the payment of handsome fees. The amount ranges from 100,000 rupees to 400,000 rupees, but typically between 150,000 to 200,000 substantial amounts indeed in India for people from ordinary families.

According to estimates by both experienced and fresher seamen, it seems that only $10-25 \%$ of all these agents are 'genuine' ones, namely, that they fulfil their promise by really providing jobs after receiving the fees. The rest are fraudsters, who, after collecting enough money, simply vanish.

Staying in the Hostel, the freshers inevitably see or hear that some of their seniors have got their jobs through agents, which seems a gamble well worth taking. The reward is alluring, because the first job is always the most difficult to get, and once they have made that 'cut', with some seagoing experience, the next job will be much easier to come by. Once they are smoothly on their track as a seafarer, they will be earning salaries that are disproportionately good compared to people in other jobs with similar education levels.

In my survey, 45 respondents, that is, $31.5 \%$ of all, reported having given bribes to agents, and the amount of money ranged from 5000 rupees to 450,000 rupees, averaging at 125,000. However, one has to take these figures again with a grain of salt. Giving money to an agent means admitting one's vulnerability and desperation. Having given the money but having not got a job means being duped. This double stigmatisation is believed to lead to deflation in the above figures. Some more experienced seamen who are by now more relaxed and therefore frank about these issues told me that freshers, out of embarrassment, would not admit the whole truth, and it is likely that $80 \%$ of all freshers will somehow end up trying bribing the agents.

However, a gamble also implies risk. In the case of the fraudulent agents, there is virtually no possibility for a victim to get his money back, because these transactions are illegal in the first place, without any record. What is more, because most of the freshers are not local residents, this cosmopolitan metropolis is also proving to be an alien and dangerous place for them. One informant told me that most freshers are from rural backgrounds and are very intimidated in such an unfamiliar environment, and they do not dare to argue with the agents or to report to police. For their own safety, they remain silent. Hard-earned or even borrowed money disappears like this, without a trace, without any hope of redress. 
By now, the foul practices of the agents are well known to most freshers, it is just a matter whether they wish to take the gamble or not. Not a few freshers seem quite determined that they are not going to be duped, just like one fresher said: 'these agents, they are all fraud! $100 \%$ !' My survey shows that among those who had not yet bribed agents, $85 \%$ suggested that they would not consider giving money in the future either, and only less than $15 \%$ indicated that they might do.

Fear of being cheated large sums of money perhaps also explains the third strategy some freshers choose to pursue, and that is through the trade unions. In India, thanks to its relatively high level of political freedom, trade union organisations flourish all over the country, and some indeed become extremely powerful and influential institutions (Candland 2001, Pandhe 2009). In the maritime sector, UnionSea (pseudonym) is the single most powerful union, and is believed by some to be the richest amongst all trade unions in India. Naturally, this union has also come to exercise considerable influence over the shipping companies and crewing agencies operating in India. A practice has also developed that when companies have vacancies, they might inform the union, and the union is in a position to recommend seafarers. In other words, for those cautious freshers who refuse to take the gamble of buying a quick but risky 'connection' from the agents, trade unions become a safer potential source from which to forge 'relationship' and obtain 'reference'.

Everyday in front of the UnionSea building in the shipping district of the city, at least 20 fresher seamen will be waiting. They dress themselves in leather shoes, office pants and shirts, some even carrying briefcases. They come before the office hours and leave only after the General Secretary (GS) of the union leaves. Day in day out, these people come unfailingly, and all they are there for is just to be able to see the GS occasionally, in the hope that the GS becomes sympathetic to their desperate need for jobs and writes them recommendation letters. Whenever the GS alights from his (chauffer driven) vehicle to enter the union building, the freshers will line up as if they were soldiers awaiting inspection. When the GS passes in front of them, the freshers are quick to salute in their nuanced Indian body language and say 'sir!' The GS, however, is busy, and only calls in the freshers once in a week and speaks to them very briefly. When asked whether such seemingly futile waiting is really worth it, one fresher who has been coming to UnionSea everyday for nearly six months told me:

He (the GS) don't have much time to give us. So we stand there, and whenever he get the time he just call us. If he can't do anything, then just he call us, and say 'keep in touch, I'll do something, keep in touch, I'll do something', means finally you can say that he's favour us. He is a very young person, but he is very good and experienced, and his mind is sound, he watches. He watch we are standing daily, whether he meet you or not it doesn't matter. His mind is sound, he watch, and he know this person is really in need... But (maybe) he counts, nobody knows. What he is seeing in you, what he is watching, you can't see, but you have to do your job: go daily and stand there, and whenever he give opportunity to tell your problem, and you just tell him, say I am suffering from this this problem... 
He and another fresher commented on the advantage of waiting at unions over searching for job through oneself or agents:

A: Listen, what happen, actually, he is my friend, and he is already given the bribe about two lakh ${ }^{6}$ to the agent. Ok, but, if you will just count, then you will find it is better to go to UnionSea ... So there are many persons who are fresher, they give the money and go to the ship; it is same that you wait here, and get the good company and carry on...

B: Only exception, we'll get a job, could be late, but free of cost, and the company and the union and the branches so many agents available in the market, you have to pay big amount, one lakh, one and half lakh, two lakh, three lakhs, then they will provide you job, could be cheat as well with you. In UnionSea, only exception you can say, you will get a job, it could be late, two months, three months, six months, because you are faced particularly before Mr Major (GS), so he provide you a letter, that you will get a job, free of cost.

However, not all unions provide jobs for free. It has been alleged by many of my informants that in recent years, many organisations have sprouted under the name of trade union, but function pretty much the same way as agents, taking money from seamen for providing jobs. This echoes Chapman's (1991: 81) observation, though made in passing, that many so-called unions 'do not have the best interests of the workers at heart'. The freshers anxiously waiting on jobs are clearly identified by many as easy prey.

\section{VULNERABILITY}

Before discussing the freshers' vulnerabilities, it is relevant to understand just why people wanted to become seamen in India in the first place. In my survey, I provided four choices regarding respondents' reasons for taking up seafaring and allowed multiple answers. As expected, good salary turned out to be by far the most common reason, with 97 (66\%) people having chosen it. Having a liking for sea or sailing came second with 47 freshers $(32 \%)$ choosing it as one of their reasons. To be able to go abroad and 'see the world' came closely after with $41(28 \%)$ hits, and finally 13 people $(9 \%)$ had chosen family background as a reason.

A question of significance when a young man decides to become a seaman is through what channel he enters this field, because entry through a regulated channel may imply a more informed decision, whereas entry through casual channels tends to expose him to various forms of exploitation. The survey reveals that as much as $63 \%$ of my respondents got to know about the training course and training institutes through their family, relative or friends; $27 \%$ through media such as newspaper, magazine or TV, only $5 \%$ through the Internet, and 5\% through other means.

In other words, though India has been internationally known for its brilliant computer engineers, the country's reliance on the Internet seems ironically low, especially amongst the lower strata of society from which most seafarers seem to originate. An information system which runs by and large on word of mouth and interpersonal 
connections necessarily leaves more room for irregularities and malpractices to the disadvantage of seamen, though the seamen's relatively low level of education also contributes to their lack of access to information. When asked whether they knew if it would be difficult to find a job after their training, 35\% of the respondents indicated 'Yes' and the rest 'No'. Most freshers have only been shown the glamorous side of seafaring, such as high salary and the chance to 'roam the world' as they put it, but whether they knew the seamy side of the picture is less clear. And it is of course in the interest of those job agents and touts to only present the glamour of the profession. The General Secretary of UnionSea comments:

Lack of information, lack of proper guidance, the person whom they went to seek guidance give them... painted a very rosy picture 'oh, it's the best of the thing; oh you will get a job like this...just do this training, and you will be off, within six months you will board a ship'...so this lack of guidance. And, some people also, they have the corruption is there, they give wrong advice, they themselves agents and touts, they give wrong guidance deliberately that 'oh, if you become...you have to give so much money. If you give this much money he will get you training done, and then if you give this much money, he will put you onboard the ship.' So people who are misguided who are not... and it is not that the people who misguided the ones, you know, illiterate one; many literate person, people who have served in the armed forces also, they also got misguided and they have also given money. I have known such people... it is not that people, you know, illiterate people, they are uneducated people got misguided...it was this type of people also. So, it is...you know...it is a sense of hope, that if you...they consider it as an investment in themselves: 'let's...even if an agent, the corruption is there, let's invest so much for a better future life, after so many years...' But not all rivers end up into the sea, you know...some rivers go around and end up in some dry valley.

Among those who have in some way bribed agents, $32.3 \%$ gave the money before they started training, and another $6.5 \%$ gave both before and after training. Through my casual interviews with the freshers, it turned out that it is quite typically the case that a young man from the rural area has seen some neighbours or relatives who have had a handsomely gainful career as a seafarer, and therefore his family through some personal contacts find an agent, who in turn demands from the candidate a lump sum higher than the course fee, and promises to both enrol the candidate and secure a job for him afterwards. Of course, such promises are rarely fulfilled - the agent either demands more money or stalls, or simply disappears. One fresher narrates his experience:

Actually what happened: my agent he told me that you finish the course, and I will put you on the ship. After finishing the course, I complete my BSc, because I have left before 2 years, then I went to my agent, he was saying ok, I will place you, but after some time he was just stucking [stalling]...what he was doing: he will say, ok now, you just go for the medical, so I went for the medical. He said 
go and take the yellow fever [test], then I take the yellow fever. Then he was saying, now, I need more 40,000 rupee, then I will place you. But I thought that it is...he is not a level person, maybe he receives 40,000 then after he will ok I want some more. Or he may put me on wrong ship. Wrong ship, you know, means not travelling, not...in the wait, maybe in the scrap or in the dock, being repaired or maintenance...go for the scrap or maintenance or whatever. There are many types of the ship, good ship, big ship, small ship, depends on the GRT [gross tonnage]... So there are many chances of deceive...

\section{Discussion}

I have in the above attempted to render a rounded description of the situation of Indian fresher ratings through selective data. While the broad focus I attempted at means that none of the aspects could be gone into in significant detail, it can be gleaned that the fresher ratings are found in profoundly precarious and vulnerable positions. Conceptualisation of precarity has so far emphasised the features of actual employment, such as remuneration, renewal terms and so on, but in this paper I broaden its scope by counting pre-employment vulnerabilities into precariousness. The supply and demand in global seafaring labour market creates a polarisation whereby highly skilled officers increasingly enjoy greater employment security and better terms (Yang 2010) whereas ratings face a profession that is significantly more casualised - with short duration of training and low entry standards - and increasingly devoid of certainty or standard practices in the context of neoliberalisation/marketisation. In fact, as the data show, as soon as freshers enter the field to search for employment, they constantly stand the danger of falling prey to a range of foul players.

In the survey, I attempted to harvest the freshers' own opinions as to who should be held responsible for their treacherous situation, by asking 'Now I cannot find a job, whose fault it is?' Their response is as follows:

Figure 1: Who the freshers think is responsible for their difficult situation

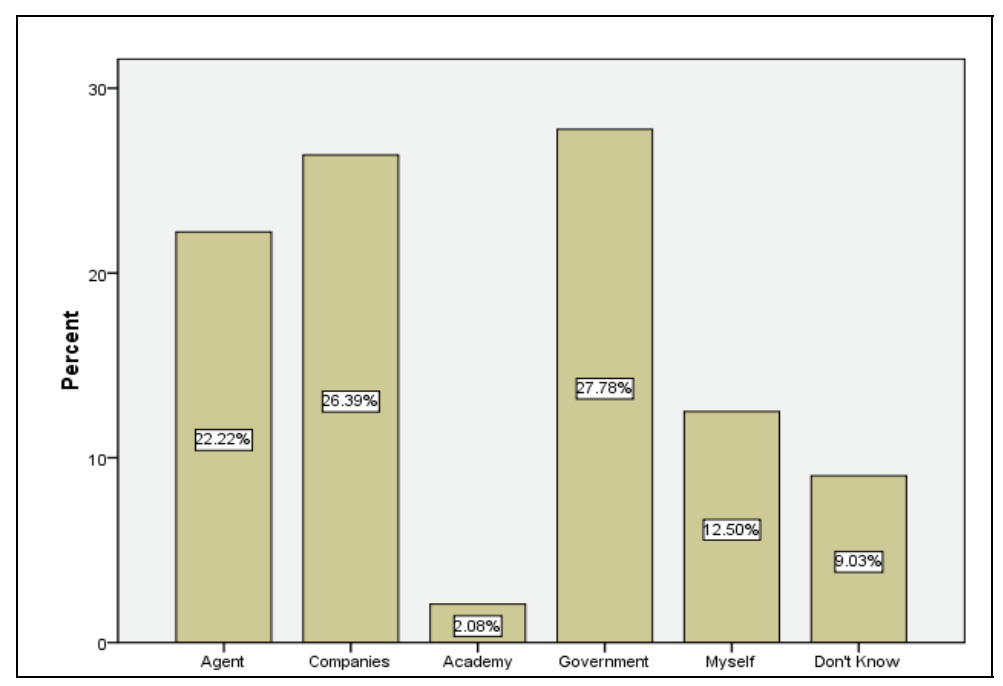


I observed that not a few participants struggled to answer this question, as if faced with a difficult exam question, but it should do no harm to try to analyse the replies that emerged. Presumably, those who blamed the agents did so out of their resentment of their foul practices, considering that many of them had been victimised. Whereas those who answered 'companies' probably did so in protest of their discrimination against freshers and their dismissive attitudes. For example, a fresher went out of the way to write on the questionnaire:

companies should recruit TRAINEESEAMANS, through examinations, accordingly to my knowledge only one or two companies recruiting in this way.

But obviously, while it is true that both the agents and companies are ruthlessly exploiting the systemic oversupply of ratings, the root of a systemic problem lies in the system, and therefore those who chose 'Academy' and 'Government' can be seen as getting closer to the crux of the problem. One informant wrote on the questionnaire: 'B'coz there is No JoB, they only Government still allow to do this course(!)'. Another wrote similarly: 'DG shipping should keep control on Academyes strength, they should maintain stability of jobs...'. Yet another simply wrote: 'close this institute!'

I interviewed a senior official in the DG Shipping, asking why the government continued to approve training establishments even though there has been clear indication of an oversupply and a series of associated problems. He seemed to be struck by the naivety of the question, and replied in an unimpressed manner, that, first of all, having some unemployment of seafarers 'is always good', because it will 'keep a pressure' on those who are employed, so that they will not become inefficient and irresponsible in discharging their work duties; secondly, because the growth prospects of global shipping is looking sanguine, it is always desirable to have some extra labour reserve so that when new employment opportunities come up, the Indian seafarers will be in a position to benefit. And the more Indians employed in the international market earning dollars, the more foreign currency will flow into the country, the official enlightened me. In other words, the systematically sustained surplus of ratings functions to discipline the Indian seafaring labour force in the competitive international labour market and to simultaneously provide a 'reserve army' which will be ready to capture greater global shares for the good of the nation. It seems to the government official that the difficulties faced by a few ratings are to be tolerated in view of the interest of the nation, though it is clear from my study that those seafarers themselves do not derive a sense of pride for being such selfless national benefactors. [A parallel could be found in Filipino overseas workers' refusal to the state's discursive appropriation of them as national heroes or heroines. See Tyner 2009.] At the intersection of India's neoliberal economic reform and its integration into a competitive global economic order as a human resource rich country, it is ironically those very humans that make up the resources who seem to have to make the sacrifices.

The disciplining of seafarers mentioned by the official also relates to another interesting point that emerges from my data, namely, the ambivalent relationship 
between job-seeking ratings and the maritime trade unions. Leaving aside those bogus trade unions which are exploitative job agencies in disguise, even for established labour unions such as UnionSea, there is as much an aspect of patronage/protection as that of discipline in their relationship with the freshers. It is well known that casual labour 'hiring halls' demand loyalty from job-seekers and thereby also exert discipline over them to regulate their behaviour on job, as Williams (2009) illustrates. The deference and obedience shown by the freshers towards the General Secretary of UnionSea indicates a parallel between the function of seafaring trade unions in India and hiring halls. Indeed, further data show very clearly that disciplining is at the very heart of the function of those Indian seafaring trade unions that I came across in my research (Yang 2010), and it may be argued that some unions discipline their members - not least the freshers - to such a degree that the unions' fundamental identity as representatives of labour could be called into question. If not for the discipline exercised by the unions, why else would employers be happy to contact the union when they have vacancies or to accept job-seekers when they have a reference or recommendation from the union? What is at play is arguably a significant shift, if not reversal, of the union's role from the side of labour to that of the capital - a phenomenon that is worth closer investigation. Nevertheless, as the purpose of the current paper remains presenting an overall understanding of the fresher ratings' situation, I shall reserve the above point for a separate study.

\section{RECOMMENDATIONS AND FURTHER RESEARCH}

Finally, if the fundamental problem lies in a systematically created oversupply, then will simply shutting down the institutes solve the problem, as some of the seafarers seemed to suggest? In a populous developing economy such as India, unemployment almost seems inevitable. This paper does not intend to fundamentally criticise the Indian Government's policy toward seafaring labour training and supply, because, considering that even though the Indian economy has been booming for the last two decade the rate of underemployment in India remains a major problem (Anant, Hasan, Mohapatra, Nagaraj and Sakikumar 2006), there is reason to believe that unemployment is a wider structural issue, instead of being specific to certain industries. In the highly stratified Indian society, it is usually those who are already at social disadvantage (low education, disadvantaged social backgrounds etc.) that elect to train as seafarers. The unemployment of fresher seafarers and their consequent vulnerabilities can hence be more appropriately understood as manifestations of the general structure and realities of the Indian economy than merely direct consequences of policy mismanagement.

However, this does not mean that there is nothing the government can do or needs to do about the frankly appalling situation the freshers face. While it would be implausible to suggest the seafaring labour market be taken back under state planning as leftist trade unionists tend to advocate, there are perhaps areas within the current system on which the authority can seek to make improvements, so that the new entrants into the market suffer less from gratuitous exploitation. For instance, the availability and access to labour market information is one urgent issue. Many young men chose to become seafarers simply based on hearsay information, with very little detailed knowledge of the profession in which they are going to invest heftily, and a labour market which they will 
join thereafter. A transparent and government supervised channel of selection and application to training colleges also seems desirable, so ignorant entrants no longer suffer at the hands of unethical middlemen or agents. The foul practices of the job agents also need to be put a bridle on, and this requires stronger law enforcement on the one hand, and better education of the fresh entrants into the labour market on the other. Lastly, for those who are in the labour market and waiting to try their luck, the government also has a responsibility to facilitate their employment-seeking by putting into place a more regulated and systematised channel of information flow. At the same time, any initiative to improve the living conditions of these 'lads in waiting' and enrich their social life so that they spend their time more meaningfully and productively are to be welcomed. For all these improvements to be possible, the government authority is in a position to take a lead role, but it also requires the involvement of other private and public stakeholders such as the shipping companies, the trade unions, and not least, the seafarers themselves.

Lastly, although this paper attempts to explore the precariousness and vulnerabilities faced by fresher seafarers in India and subsequently to make some suggestions and recommendations, the limitations of all of these attempts have been obvious. Examining from a very restricted perspective, namely focusing on the fresher seamen staying in one single Hostel, the various problems can only be said to have been probed, but not studied in any depth. Topped by further difficulties such as the lack of resources to do a more extensive study, the suggestions made above are also done in broad strokes, and wait to be filled out and refined by further research efforts. Nevertheless, it is hoped that this paper, by describing the situation of this group of Indian 'lads in waiting', opens to the readers another potentially fruitful field in which to examine how neoliberal globalisation profoundly and often deleteriously impacts labour across industries and countries.

\section{ACKNOWLEDGEMENTS}

I would like to thank my supervisors Professor Helen Sampson and Professor Mick Bloor at Cardiff University, who provided comments on earlier drafts of the paper, and the Nippon Foundation for generously funding my research degree. My thanks also go to the two anonymous reviewers who gave very constructive and encouraging comments. But I would like to dedicate this paper to Mr Naresh Birwadkar, Mr Antony Joseph, Mr Swanesh Chaurashia and many other Indian friends who I cannot afford to name in full, for the incredible friendliness, helpfulness and cooperation they extended me throughout my stay in India.

\section{NOTES}

\footnotetext{
${ }^{1}$ According to Drewry Shipping Consultants Limited. See www.bharatbook.com/Market-Research-Reports/Manning-2009.html. Accessed 18 August 2010.
} 
${ }^{2}$ See article: Steps Needed to Promote Seafaring (2009) at http://www.intermanager.org/Resources/News/tabid/82/mid/500/newsid500/292/Defaul t.aspx. Accessed 14 May 2010.

${ }^{3}$ See various in-house publications of Seafarers International Research Centre (SIRC): www.sirc.cf.ac.uk.

${ }^{4}$ Directorate General of Shipping (DG Shipping) is a directorate under the Shipping Wing of the Indian Ministry of Surface Transport. DG Shipping is the overall regulator of the shipping industry in India, and its authority scope covers issues ranging from the development of Indian shipping industry, to maritime safety, to the training, employment and welfare of seafarers. See www.dgshipping.com. Accessed 4 February 2010.

${ }^{5}$ Currently, roughly 47 rupees are worth 1 US dollar.

${ }^{6}$ Indian numeric unit, equals 100,000 .

\section{REFERENCES}

Alderton, T., Bloor, M., Kahveci, E., Lane, T., Sampson, H., Thomas, M., et al. (2004) The Global Seafarer: Living and Working Conditions in a Globalized Industry. Geneva: International Labour Office.

Alderton, T. and Winchester, N. (2002) 'Globalisation and De-regulation in the Maritime Industry’, Marine Policy 26(1): 35-43.

Anant, T. C. A., Hasan, R., Mohapatra, P., Nagaraj, R. and Sakikumar, S.K. (2006) 'Labor Markets in India: Issues and Perspectives', in J. Felipe and R. Hasan (eds), Labor Markets in Asia: Issues and Perspectives (pp. 205-300). New York: Palgrave Macmillan.

Barnes, B.L. (1989) Mental Health of Indian Seafarers. London: International Transport Worker's Federation (ITF).

BIMCO/ISF (2005) Manpower 2005 Update: The Worldwide Demand for and Supply of Seafarers.

Bonnin, D., Lane, T., Ruggunan, S. and Wood, G. (2004) 'Training and Development in the Maritime Industry: The Case of South Africa', Human Resource Development International 7(1): 7-22.

Burawoy, M. (ed) (2000) Global Ethnography: Forces, Connections, and Imaginations in a 
Postmodern World. Berkeley: University of California Press.

Candland, C. (2001) 'The Cost of Incorporation: Labor Institutions, Industrial Restructuring, and New Trade Union Strategies in India and Pakistan', in C. Candland and R. Sil (eds). The Politics of Labor in a Global Age: Continuity and Change in Late-industrializing and Post-socialist Economies (pp. 69-94). Oxford: Oxford University Press.

Carlisle, R. (1981). Sovereignty For Sale: The Origins and Evolution of the Panamanian and Liberian Flags of Convenience. Annapolis: Naval Institute Press.

Chapman, P.K. (1991) Trouble on Board: The Plight of International Seafarers. Ithaca, New York: ILR Press.

Cleaveland, C. and Pierson, L. (2009) 'Parking Lots and Police: Undocumented Latinos Tactics for Finding Day Labor Jobs', Ethnography 10(4): 515-533.

Couper, A.D., Walsh, C.J., Stanberry, B.A. and Boerne, G.L. (1999) Voyages of Abuse: Seafarers, Human Rights, and International Shipping. London: Pluto.

Desai, D.D. (1940) Maritime Labour in India. Bombay: Servants of Indian Society.

Donner, P. (2009) Reasons for and Insurance Implications of the Manning Crisis. Paper presented at the Alandia Marine Insurance Seminar 'Crew Quality'. Mariehamm, 2 April.

Frost, D. (ed) (1995) Ethnic Labour and British Imperial Trade: A History of Ethnic Seafarers in the UK. London: Frank Cass and Company Ltd.

Glen, D. (2008) 'What Do We Know About the Labour Market for Seafarers? A View from the UK', Marine Policy 32(6): 845-855.

Hammersley, M. and Atkinson, P. (1995) Ethnography: Principles in Practice (2nd edition). London: Routledge.

Hendry, J. (2003) 'An Ethnographer in the Global Arena: Globography Perhaps?', Global Networks 3(4): 497-512.

Kalleberg, A.L. (2009) 'Precarious Work, Insecure Workers: Employment Relations in Transition', American Sociological Review 74(1): 1-22.

Leggate, H. (2004) 'The Future Shortage of Seafarers: Will it Become a Reality?', Maritime Policy and Management 31(1): 3-13. 
Li, K.X. and Wonham, J. (1999) 'Who Mans the World Fleet? A Follow-up to the BIMCO/ISF Manpower Survey'. Maritime Policy and Management 26(3): 295-303.

Lillie, N. (2006) A Global Union for Global Workers: Collective Bargaining and Regulatory Politics in Maritime Shipping. London: Routledge.

Matthews, S. (2007) 'Cost Push'. Lloyd's Shipping Economist. 1 March.

Metaxas, B.N. (1985) Flags of Convenience: A Study of Internationalisation. Aldershot: Gower.

Obando-Rojas, B. (2003) 'New Jobs for Seafarers in Short Supply'. The Sea Mar/Apr (162).

Pandhe, M.K. (2009) Trade Union Movement in India: Yesterday, Today and Tomorrow. Paper presented at the Working Class Movement in India: Past, Present and Future at the University of Mumbai, Mumbai, 24-25 September.

Purser, G. (2009) 'The Dignity of Job-Seeking Men: Boundary Work Among Immigrant Day Laborers', Journal of Contemporary Ethnography 38(1): 117-139.

Rao, T.S.S. (1965) A Short History of Modern Indian Shipping. Bombay: Popular Prakashan.

Rodgers, G. and Rodgers, J. (eds) (1989) Precarious Jobs in Labour Market Regulation: The Growth of Atypical Employment in Western Europe. Geneva: International Labour Organisation.

Sampson, H. (2003) 'Transnational Drifters and Hyperspace Dwellers: An Exploration of the Lives of Filipino Seafarers Aboard and Ashore', Ethnic and Racial Studies 26(2): 253-277.

Sampson, H. (2004) 'Romantic Rhetoric, Revisionist Reality: The Effectiveness of Regulation in Maritime Education and Training', Journal of Vocational Education and Training 56(2): 245-268.

Sampson, H. (2005) 'Left High and Dry? The Lives of Women Married to Seafarers in Goa and Mumbai', Ethnography 6(1): 61-85.

Shao, J., Yang, P. and Zhang, M. (2008) Ship Operation from a Shipmanager's Perspective. Unpublished Bachelor of Science in Maritime Studies Dissertation, Nanyang Technological University, Singapore. 
Slater, J. (1984) 'Cheap Foreign Labour: Empire Relic with no Place in Civilized Society', Marine Policy 8(1): 64-65.

Stopford, M. (1997) Maritime Economics. London; New York: Routledge.

Thanopoulou, H.A. (1998) 'What Price the Flag? The Terms of Competitiveness in Shipping', Marine Policy 22(4-5): 359-374.

Theodore, N. (2002) 'Political Economies of Day Labour: Regulation and Restructuring of Chicago's Contingent Labour Markets', Urban Studies 40(9): 1811-1828.

Tyner, J.A. (2009). The Philippines: Mobilities, Identities, Globalization. New York and London: Routledge.

Venkatesh, S. (2002) "'Doin' the Hustle": Constructing the Ethnographer in the American Ghetto', Ethnography 3(1): 91-111.

Williams, D.T. (2009) 'Grounding the Regime of Precarious Employment: Homeless Day Laborers' Negotiation of the Job Queue', Work and Occupations 36(3): 209-246.

Yang, P. (2010) Romance of The Three Unions: A Comparative Study of the Identity Discourses of Three Indian Maritime Trade Unions. Unpublished thesis, Cardiff University.

Zhao, A. and Amante, M.S.V. (2003) 'Chinese Seafarers and Filipino Seafarers: Race to the Top or Race to the Bottom?', SIRC Symposium 2003, Cardiff University, 19 September. ISBN 1-900174-22-7.

\section{BIOGRAPHICAL NOTE}

Peidong Yang is a Nippon Foundation Fellow at the Seafarers International Research Centre (SIRC), a constituent research centre of the School of Social Sciences, Cardiff University. Funded by the Nippon Fellowship, he has just completed an MPhil in Social Sciences at Cardiff University, studying the discursive identity constructions of Indian maritime trade unions. He is soon due to start his doctoral studies in education at the University of Oxford. 